\title{
Extraction and Characterization of Listeria monocytogenes Exopolysaccharide
}

\author{
Raghad R. Al-Abbasi \\ Department of Biophysics \\ Sahira I. Al-Sanjary \\ College of Science/ University of Mosul
}

(Received 4/3/2014; Accepted 5/ 5 / 2014)

\begin{abstract}
This study was aimed to extract exopolysaccharide (EPS) produced by Listeria monocytogenes and investigate the maximum production by using different culture media and various factors. The EPS was obtained from the culture supernatant by cold ethanol precipitation and yield maximum production $(0.368 \mathrm{mg} / \mathrm{ml})$ in basal salt solution (BSS) as dry weight. The total carbohydrate content was determined by phenol sulfuric acid method. The functional groups were detected by Fourier transform infrared (FTIR) spectroscopy at frequency range of 400- 4000 $\mathrm{cm}^{-1}$. Different alcohols were checked for their efficiency on precipitating EPS, those other than ethanol, methanol and isopropanol were able to sediment the EPS, while isoamylalcohol show no effect on precipitation. The results also indicated that the medium volume play an important role in EPS production.
\end{abstract}

Keywords : Listeria monocytogenes, EPS, FTIR spectroscopy.

\section{Listeria monocytogenes استخلاص و توصيف متعدد السكريات الخارجي لجراثيم}

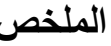

تضمنت الدراسة استخلاص متعدد السكريات الخارجي(EPS) المنتج من قبل Listeria monocytogenes للحصول على أعلى إنتاجية باستخدام أوساط غذائية مختلفة وتأثير عوامل مختلفة. نم ترسيب متعدد السكريات الخارجي من راشح المزرعة باستخدام الاينانول المبرد وكانت أعلى إنتاجية (0.368) ملغم /مل كوزن جاف باستخدام وسط المحلول الملحي (BSS) وقدر محتوى الكاربوهيدرات الكلي باستخدام طريقة الفينول-حامض الكبريتيك. تم تحديد المجاميع التركيبية باستخدام طيف الأشعة تحت

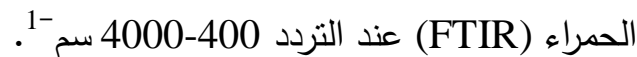

استخدمت أنواع مختلفة من الكحولات وقد اظهر الايثانول والميثانول والايزوبروبانول كفاءة في ترسيب EPS، في حين ان ايزوامايل الكحول لم يظهر أي تأثثر في الترسيب.أظهرت النتائج أيضا أن حجم الوسط الزرعي يلعب دورا مهما في إنتاج متعدد السكريات الخارجي.

\section{INTRODUCTION}

Listeria monocytogenes is a Gram-positive, facultative anaerobic, non-spore-forming, rodshaped bacterium with optimal growth temperature range of $30-37^{\circ} \mathrm{C}$. It is one of the major foodborne pathogen causing disease in both humans and animals and has affected the food industries due to contamination of equipments that lead to cross contamination on food products (Chen et al., 2010; Pagadala et al., 2012). Contamination of surfaces in the processing environment can be attributed to attachment of pathogenic bacteria. Consequently, attachment of pathogenic microbes leads to biofilm formation that will occurs when microcolony formed on the surface adheres with a conditioning film that traps the surrounding fluid and nutrients (Sauer et al., 2007; Lee et al., 2013). 
Microbes release polysaccharides extracellularly as exopolysaccharides (EPSs) into the environment, the naturally occurring polysaccharides possess a unique combination of functional and environmental friendly features. they are renewable in nature, nontoxic, and biodegradable (Freitas et al., 2011). EPS is located at the cell surface of, or outside and detached from bacteria and can fill the space between cells existing in a colony, substances associated with exopolymeric matrices have multiple functions. Some serve as signaling molecules or messengers and others are energy and nutrient reserves with an important role in polymer degradation and surface adhesion (Marvasi et al., 2010).

EPS is often produced at a lower temperature than is required for optimum growth (Abdul Razak et al., 2013). It also requires higher carbon content in the medium and decreased nitrogen quantity, factors that could influence the production of EPS are the composition of the medium, especially carbon and nitrogen sources, and parameters like $\mathrm{pH}$, temperature, and incubation time (Morikawa., 2006). EPS may be produced through specific biosynthetic pathways and are then exported and actively translocated to the cell surface. It can also be produced by spontaneous liberation of integral cellular components and different mechanisms to produce EPS are adopted by different bacterial species (Flemming et al., 2007; Marvasi et al., 2010).

The aim of this study was to evaluate the production of exopolysaccharide by Listeria monocytogenes and study of some factors that affect its production.

\section{Bacterial isolate and culture medium}

\section{MATERIALS AND METHODS}

The organism Listeria monocytogenes was isolated from a clinical sample, and identified by using API- 20 techniques, obtained from Bacterial Strains Bank Unit / Biology department / College of Science in Mosul University. Listeria monocytogenes was maintained in tryptic soy broth (TSB) with $20 \%$ glycerol at $-80^{\circ} \mathrm{C}$. Cells were subcultured by inoculating brain heart infusion (BHI) and incubating at $37^{\circ} \mathrm{C}$ for $24 \mathrm{~h}$. The purified culture was stored on nutrient agar slant at $4^{\circ} \mathrm{C}$ as stock for further study.

\section{Production of EPS}

To find the optimal culture medium to produce EPS by L. monocytogenes, the following media were used: basal salt solution (BSS) (Bragadeeswaran et al., 2011), nitrogen- free medium (NFM), and chemically defined medium (CDM). For the primary EPS production, $100 \mathrm{ml}$ of each culture medium was prepared and inoculated with L. monocytogenes and then incubated at $37^{\circ} \mathrm{C}$ for 4 days (Borgio et al., 2009).

\section{Extraction of EPS}

Bacterial culture was centrifuged at $5000 \mathrm{rpm}$ for $15 \mathrm{~min}$ ( REMI motors LTD (India)), the supernatant was collected and mixed with an equal volume of cold ethanol and incubated at $4{ }^{\circ} \mathrm{C}$ for $24 \mathrm{hr}$. The precipitated EPS was collected by centrifugation at $5000 \mathrm{rpm}$ for $20 \mathrm{~min}$, then dried at $70^{\circ} \mathrm{C}$ until it was completely dried, then labeled as crude EPS. The EPS pellet was weighted before and after drying and considered as wet and dry weight respectively (Savadogo et al., 2004).

\section{Characterization of EPS}

\section{Estimation of total carbohydrate and protein contents of EPS}

Colorimetric analysis was used for determination of total carbohydrate content in the culture supernatant by phenol-sulfuric acid method using glucose as a standard monitoring. The absorbance was measured at $488 \mathrm{~nm}$ (CEC1L,CE7200 (U.K.)), Protein content was determined by Lowery method with bovine serum albumin as standard (Dubois et al., 1956 ; Lowry et al., 1951).

\section{Infra-Red spectroscopy analysis of EPS}

The crude EPS was analyzed by the Fourier Transform infrared (FTIR) spectrophotometer (Biotech engineering management CO. LTD. (U.K.)). One part of the EPS pellet was mixed with nine part of potassium bromide powder $(\mathrm{KBr})$ and then compressed into a thin disk. The disk was 
then used for FTIR spectroscopy with the wave lengths ranging from 400 to $4000 \mathrm{~cm}^{-1}$, to detect the $\mathrm{C}=\mathrm{O}$ and $-\mathrm{OH}$ bonds in the sample (Vidhyalakshmi and Nachiyar, 2011).

\section{Effect of different alcohols on EPS precipitation.}

Firstly, to determine the efficiency of alcohols on EPS extraction, we compared between the effect of ethanol and a three chosen types of alcohols (methanol, isoamylalcohol, isopropanol) to precipitate and yield the highest EPS. An equal volume of tested alcohols were added to four flasks each which contains $25 \mathrm{ml}$ of the supernatant obtained from the culture medium. The precipitated EPS was observed after incubation over night at $4^{\circ} \mathrm{C}$, the precipitate was collected after centrifugation at $5000 \mathrm{rpm}$ at room temperature for $20 \mathrm{~min}$., and then dried at $70^{\circ} \mathrm{C}$ and weighted (Abdul Razack et al., 2013). Secondly, dependent on the obtained results and to find the best ratio of the best tested alcohol through extraction, different volumes (ratio) of the best alcohol was added to $20 \mathrm{ml}$ of supernatant as follows: $(1: 1,1: 2,1: 3,1: 4,1: 5)$ the result was observed after overnight incubation at $4^{\circ} \mathrm{C}(\mathrm{Xu}, 2007)$.

\section{Effect of culture medium volume on EPS production}

To examine the effect of medium volume to yield maximum EPS, various culture volumes of BSS medium $(20,40,60,80, \mathrm{ml})$ were added in $100 \mathrm{ml}$ flask then inoculated with $L$. monocytogenes and incubated aerobically at $37^{\circ} \mathrm{C}$ for 4 days (Wang et a ., 2011).

\section{RESULTS AND DISCUSSION}

Production of EPS on different media and its functional group analysis by FTIR spectroscopy

With a concern to find out the ability of L. monocytogenes to produce EPS in different chosen media, the quantity of EPS produced was determined and the results are shown in (Fig. 1), large amount of EPS production $(0.368 \mathrm{mg} / \mathrm{ml})$ was obtained in BBS medium flowed by CDM medium, the lowest EPS production was recorded with NFM medium $(0.102 \mathrm{mg} / \mathrm{ml})$ as dry weight.

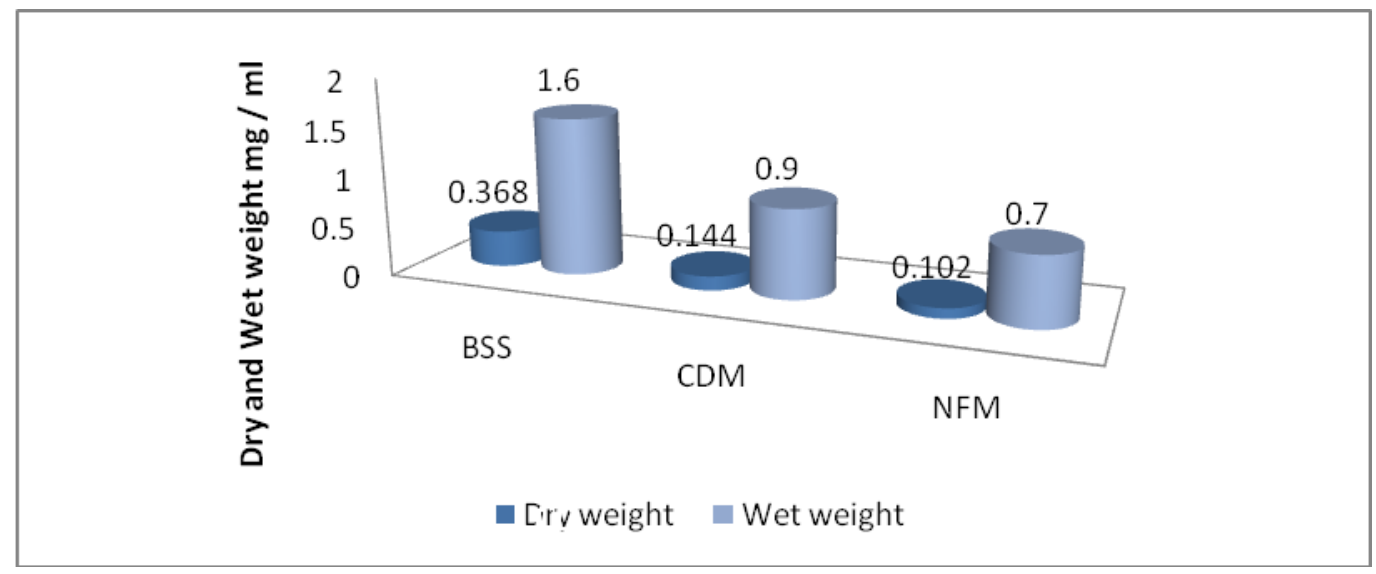

Fig 1: Quantity of EPS (mg / ml) on different media

The weight of EPS, carbohydrate concentration obtained using BSS medium $(1790 \mu \mathrm{g} / \mathrm{ml})$ was greater than that of CDM $(960 \mu \mathrm{g} / \mathrm{ml})$ and NFM $(780 \mu \mathrm{g} / \mathrm{ml})$ as shown in (Fig. 2). 


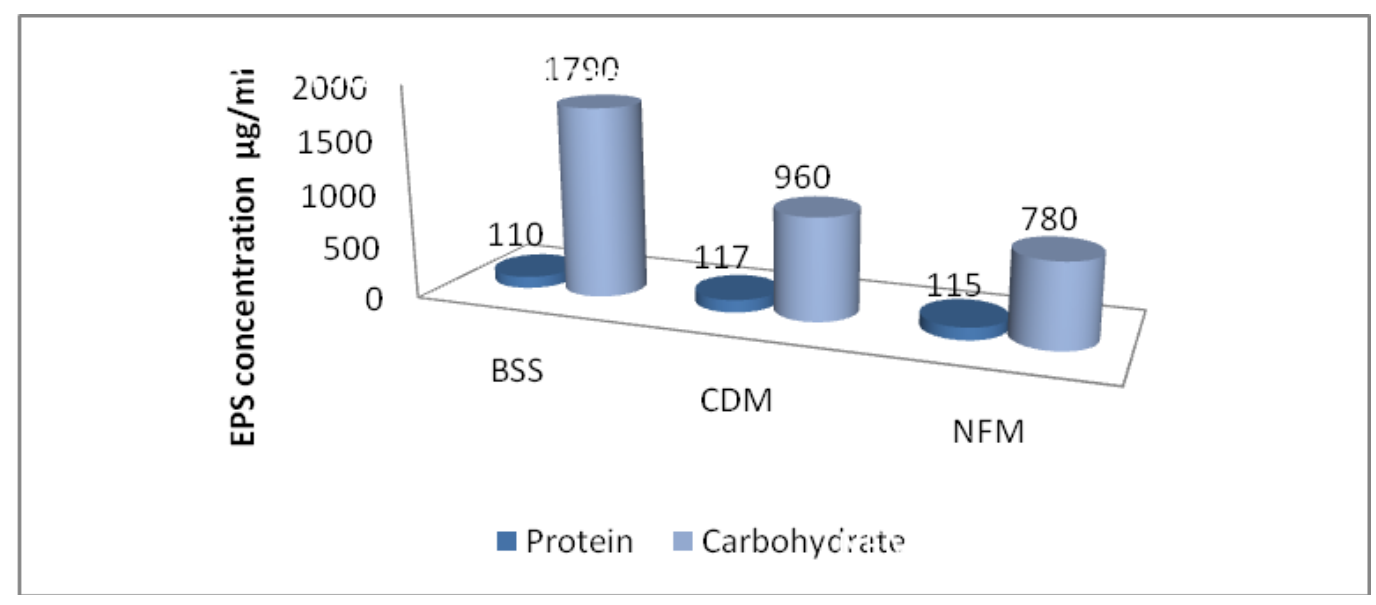

Fig. 2: Total carbohydrate and protein concentrations of EPS extracted by different media

The results from the FTIR spectroscopic analysis of EPS produced by the bacteria under study for the three tested media indicates the presence of different function groups such as $\mathrm{C}=\mathrm{O}, \mathrm{COOH}$, and $\mathrm{OH}$ groups. The FTIR spectra showed the presence of the characteristic bands for OH group at $3350 \mathrm{~cm}^{-1}, 3327 \mathrm{~cm}^{-1}$ and $3384 \mathrm{~cm}^{-1}$ in BSS, CDM and NFM, respectively. The absorbance peak at $2924 \mathrm{~cm}^{-1}$ for BSS and NFM, and at $2925 \mathrm{~cm}^{-1}$ for CDM indicate the presence of C-H aliphatic group. The intensity of the bands at $1662 \mathrm{~cm}^{-1}$ in BSS and CDM, at $1655 \mathrm{~cm}^{-1}$ in NFM was due to $\mathrm{C}=\mathrm{O}$ bond (Figs. 3, 4, 5).According to the obtained results of FTIR analysis and corresponding to the amount of yielded EPS, the BSS medium showed higher efficacy in supporting $L$. monocytogenes to produce large amount of EPS, so this medium was depended to estimate the EPS in the current study.

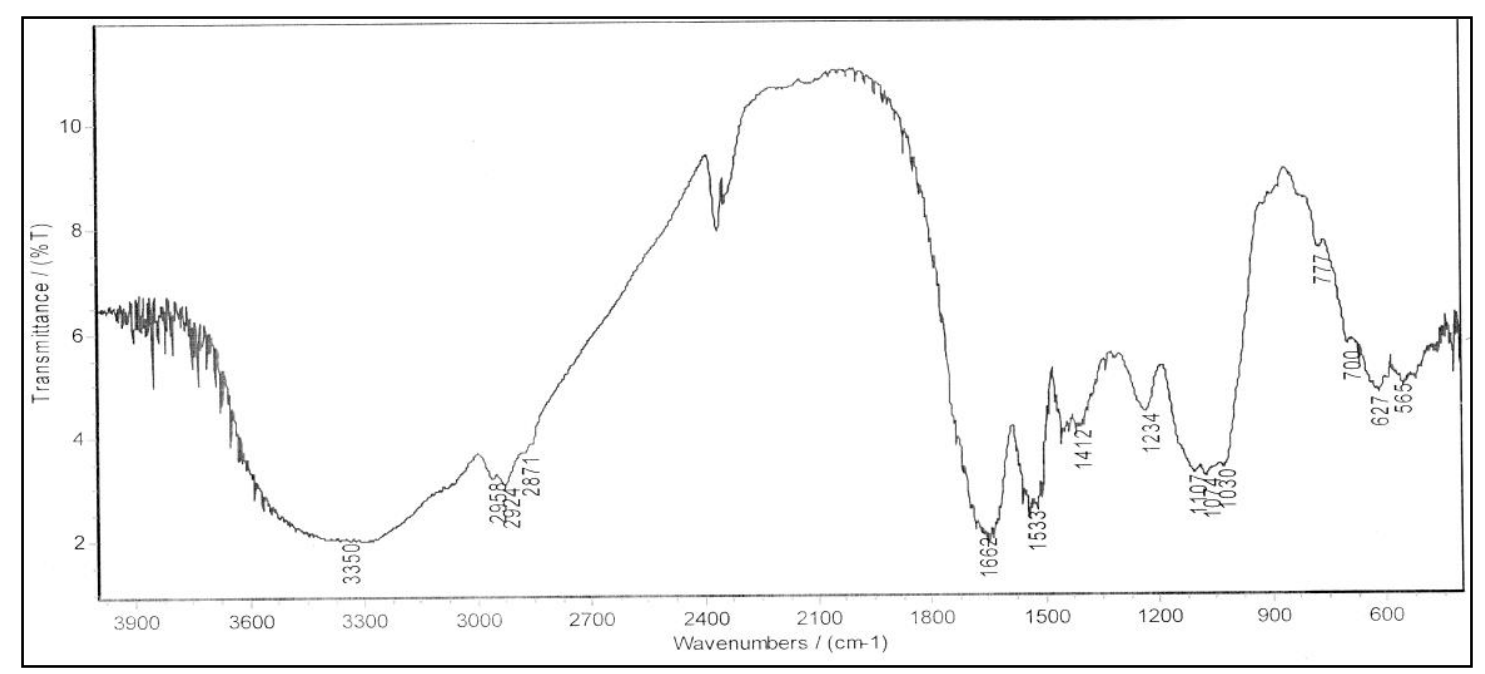

Fig. 3: FTIR analysis of L.monocytogenes EPS from BSS medium 




Fig. 4: FTIR analysis of L.monocytogenes EPS from CDM medium

The BSS medium was suitable for production of EPS which it contains carbon and nitrogen source greater than the other media. Many studies indicated that although the composition and amount of EPS produced by a bacterium are genetically determined traits, they are highly influenced by media components and cultivation conditions, and the extracellular biopolymers'synthesis by microbial cells depends on the carbon and nitrogen availability in the culture medium and EPS synthesis is generally favored by the presence of a carbon source in excess. Most exopolymer-producing microorganism sutilize carbohydrates as their carbon and energy source and either ammonium salts and amino acids as their source of nitrogen (Freitas et al., 2011; Czaczyk and Wojciechowska, 2003).

The BSS also contain 3.5\% sodium chloride $(\mathrm{NaCl})$ and this salt will enhance the EPS production, Pan et al., (2010) found that when the colonies of L. monocytogenes were incubated with tryptic soy broth as nutrient and $\mathrm{NaCl}$ as additional nutrients, the formation of biofilm was enhanced as a synergistic effect on the combination of glucose, $\mathrm{NaCl}$ and TSB. On the other hand Lee and his colleagues (2013) in their studies on the effect of sodium chloride on L.monocytogenes ATCC 19112 (serogroup 1/2c), the organism was placed on the cellular stress by $\mathrm{NaCl}$ instead of $\mathrm{NaCl}$ as additional nutrient to the cells, they showed that this microorganism was able to form biofilm with minimal nutrient requirements, for example, in presence of $\mathrm{NaCl}$ only.

Wong (2012) showed that when Listeria grown in a minimal medium (D10 and MCDB202) it produced more capsule-like material than those grown in a rich media (BHI) when imaged using SEM. From this image it can been seen that Listeria cells grown in BHI appears as separate, single rods showing little evidence of EPS formation, where as the cells grown in minimal media were surrounded by avisible coating of EPS, and also were surrounded by strings-like structure spanning between cells. 


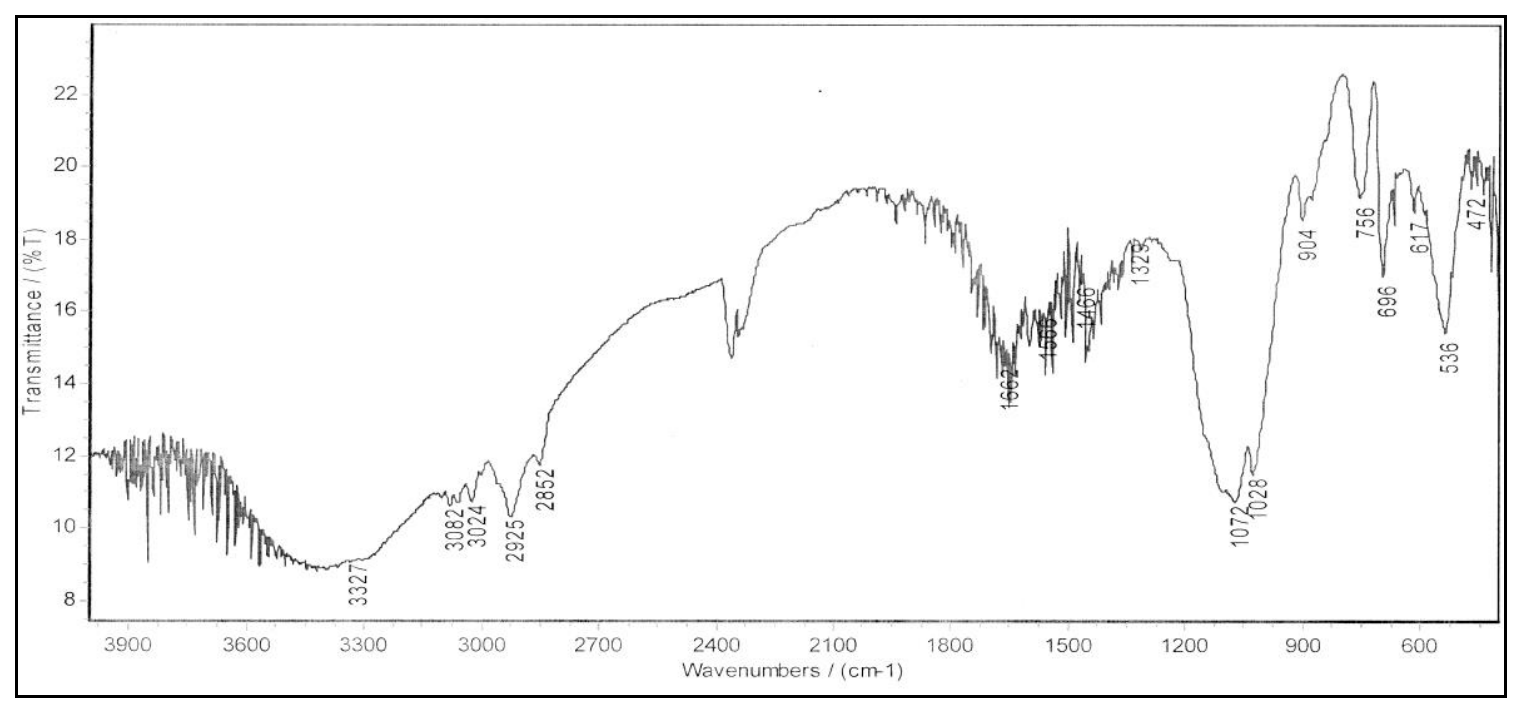

Fig. 5: FTIR analysis of L.monocytogenes EPS from NFM medium

\section{Effect of different alcohols on EPS precipitation.}

When we compared between ethanol and other alcohols on the ability to precipitate L.monocytogenes EPS, we found that cold ethanol gave higher yield of EPS $(0.64 \mathrm{mg} / \mathrm{ml})$ after 24 hours considered as dry weight (Fig. 6).



Fig 6: Effect of different alcohols onL.monocytogenes EPS precipitation

The amount of total carbohydrate in BSS medium was $(313 \mu \mathrm{g} / \mathrm{ml})$ and the amount of crude EPS after precipitation also indicates ethanol was the best precipitate for EPS that yield $(588 \mu \mathrm{g} / \mathrm{ml})$ while isopropanol led to the lowest yield $(94 \mu \mathrm{g} / \mathrm{ml})($ Fig .7). 


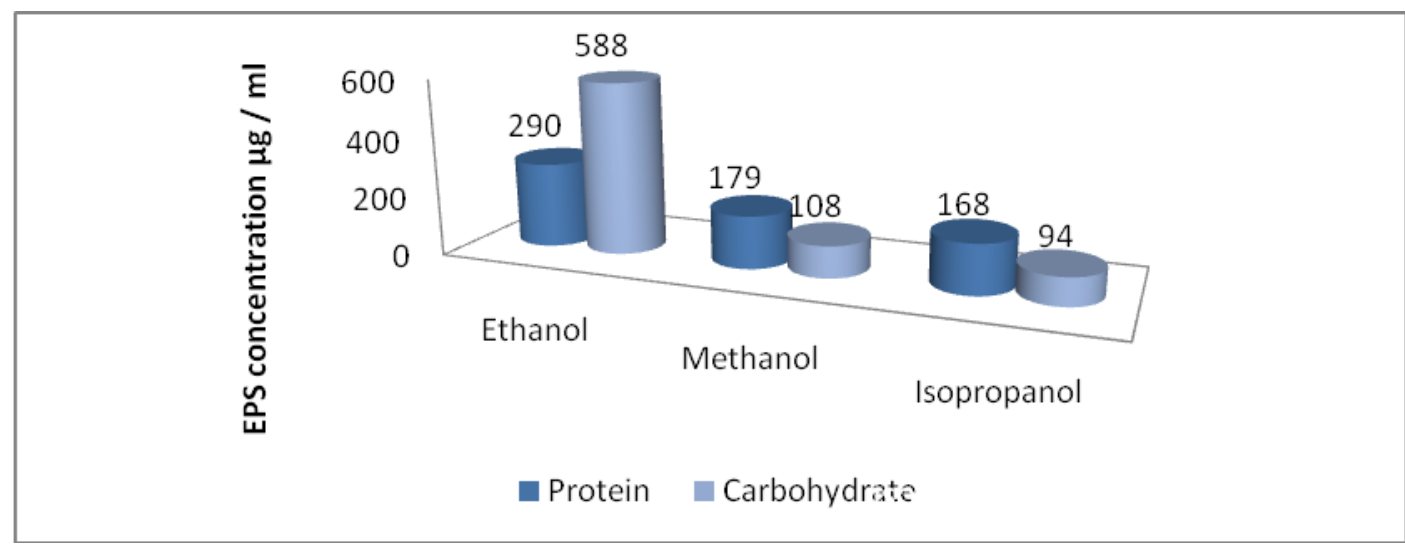

Fig. 7: Total carbohydrate and protein concentrations of EPS extracted by different alcohols

In this study, various solvents were tested for their efficiency in extracting the EPS from the culture. The results showed that the standard solvent was ethanol, it precipitated EPS with in $24 \mathrm{~h}$ and overnight incubation.where as methanol sedimented EPS instantly upon addition to the culture supernatant. Ethanol precipitate polysaccharides preferentially and it was represent the standard alcohol used to extract exopolysaccharide from microorganisms in most other studies (Qiang et al., 2013). In the extraction method of EPS from Bacillus subtilis (Abdul Razack et al., 2013) recorded that methanol sedimented EPS instantaneously upon addition to the culture supernatant where as when they used ethanol it required $24 \mathrm{~h}$ for incubation to precipitate EPS.

Our results revealed that isopropanol showed effective action but less than ethanol, other study also used cold isopropanol in EPS purification from Staphylococcus aureus (Kolodkin-Gal, et al.,2012), but $\mathrm{Xu}$, (2007) demonstrated that isopropanol precipitated protein more than polysaccharides. According to our results isoamylalcohol showed no effect on extraction of EPS because after the addition of isoamylalcohol to the culture supernatant for $24 \mathrm{~h}$. there was no obtained EPS pellet and the solution stay as two separated layers even after $48 \mathrm{~h}$, this is also reported by Abdul Razack and his colleagues (2013) when they found the same result as they showed a form of white interface at the junction between solvent and supernatant which apparently consist of lipids and proteins.

According to previous results ethanol was depended as the best precipitating agent to produce EPS by L.monocytogenes, and to find the best ratio for precipitating, we found that when we added (100)ml ethanol to $20 \mathrm{ml}$ supernatant it gave higher yield of EPS $(6.90 \mathrm{mg} / \mathrm{ml})$ as dry weight, The amount of total carbohydrate in BSS medium was $(8800 \mu \mathrm{g} / \mathrm{ml})$ and the amount of crude EPS after precipitation was yield $(6300 \mu \mathrm{g} / \mathrm{ml})$ (Table 1). The same conclusion was observed in Pseudomonas fluorescens Biovar II, where Xu (2007) recorded that using $75 \%$ ethanol volume yield higher total carbohydrate.

Table 1: Effect of different ethanol volume on L.monocytogenes EPS precipitation

\begin{tabular}{|c|c|c|c|c|}
\hline \multirow{2}{*}{ Ethanol ratio } & \multicolumn{4}{|c|}{ Estimation of EPS } \\
\cline { 2 - 5 } & $\begin{array}{c}\text { Wet weight } \\
(\mathbf{m g} / \mathbf{m l})\end{array}$ & $\begin{array}{c}\text { Dry weight } \\
(\mathbf{m g} / \mathbf{m l})\end{array}$ & $\begin{array}{c}\text { Carbohydrate } \\
(\boldsymbol{\mu g} / \mathbf{m l})\end{array}$ & $\begin{array}{c}\text { Protein } \\
(\boldsymbol{\mu g} / \mathbf{m l})\end{array}$ \\
\hline $1: 1$ & 4.8 & 1.6 & 3500 & 9200 \\
\hline $1: 2$ & 6.1 & 2.3 & 5900 & 9500 \\
\hline $1: 3$ & 10.25 & 2.75 & 6100 & 9600 \\
\hline $1: 4$ & 12.15 & 4.95 & 6200 & 9700 \\
\hline $1: 5$ & 23.8 & 6.90 & 6300 & 9800 \\
\hline
\end{tabular}

\section{Effect of medium volume on EPS production}


The correlation between the resulted EPS with the different culture medium volume was pointed up (Table 2). The higher EPS production was obtained when the culture medium volume was (40) $\mathrm{ml}$ in $100 \mathrm{ml}$ flask, so the medium liquid volume may play an important role in EPS production, the same result of that reported by Wang and his colleagues (2011) which also found that $25 \mathrm{ml}$ of culture medium volume in $200 \mathrm{ml}$ flask give maximum EPS produced by Bacillus thuringiensis 27 .Several studies have reported that medium volume was vital in order to increase aeration during incubation process, which had a great effect on the cell growth and EPS production and conclude that the aeration stimulate extracellular polysaccharide production (Czaczyk and Myszka, 2007; Vu et al., 2009; Poli et al., 2010). The production of most bacterial EPS occurs under aerobic conditions, for optimal production of some EPSs maximal aeration was required (e.g. xanthan gum) where as for others, synthesis is maximized under microaerophilic conditions (e.g. bacterial alginate) (Freitas et al., 2011). Also Qiang and his colleagues (2013) observed that EPS produced from Klebsiella sp.H-207 was slightly affected under a medium volume range of 20 to $60 \mathrm{ml}$ and then it decline sharply when medium volumes were more than $60 \mathrm{ml}$.

\section{Table 2: Effect of medium volume on EPS production}

\begin{tabular}{|c|c|c|}
\hline \multirow{2}{*}{ medium volume $(\mathbf{m l})$} & \multicolumn{2}{|c|}{ Estimation of EPS } \\
\cline { 2 - 3 } & $\begin{array}{c}\text { Carbohydrate } \\
(\boldsymbol{\mu g} / \mathbf{m l})\end{array}$ & $\begin{array}{c}\text { Protein } \\
(\boldsymbol{\mu g} / \mathbf{m l})\end{array}$ \\
\hline 20 & 77 & 194 \\
\hline 40 & 84 & 152 \\
\hline 60 & 82 & 150 \\
\hline 80 & 74 & 128 \\
\hline
\end{tabular}

\section{REFERENCES}

Abdul Razak, S.; Velayntham, V.; Thangavelu, V. (2013). Medium optimization for the production of exopolysaccharide by Bacillus subtilis using synthetic sources and agro wastes. Turk. J. Biol., 37, 1-7.

Borgio, J.F.; Bency, B.J.; Ramesh, S.; Amuthan, M. (2009). Exopolysaccharide production by Bacillus subtilis NCIM 2063, Pseudomonas aeruginosa NCIM 2862 and Streptococcus mutans MTCC 1943 using batch culture in different media. Afr. J. Biotechnol., 8(20), 5454 -5457.

Bragadeeswaran, S.; Jeevapriya, R.; Prabhu, K.; Sophia Rani, S.; Priyadharsini, S.; Balasubramanian, T. (2011). Exopolysaccharide production by Bacillus cereus GU812900, a fouling marine bacterium. Afr. J. Microbiol. Res., 5(24), 4124-4132.

Chen, B.Y.; Pyla, R.; Kim, T.J.; Silva, J.L.; Jung, Y.S. (2010). Prevalence and contamination patterns of Listeria monocytogenes in catfish processing environment and fresh fillets. Food. Microbiol., 27(5), 645-652.

Czaczyk, K.; Wojciechowska, K. (2003). Formation of bacterial biofilms - the essence of the matter and mechanisms of interactions. Biotechnol., 3,180.

Czaczyk, K.; Myszka, K. (2007). Biosynthesis of Extracellular Polymeric Substances (EPS) and Its Role in Microbial Biofilm Formation. Polish J. Environ. Stud., 16(6), 799-806.

Dubois, M.; Gilles, K. A.; Hamilton, J.K.; Rebers, P. A.; Smith. F. (1956). Colorimetric method for determination of sugars and related substances. Anal. Chem., 28, 350-356

Flemming, H.C.; Neu, T.R.; Wozniak, D.J. (2007). The EPS Matrix: The House of Biofilm Cells . J. Bacteriol., 189, 7945-7947.

Freitas, F.; Alves, V.D.; Reis, M.A.M. (2011). Advances in bacterial exopolysaccharides: from production to biotechnological applications. Trends Biotechnol., 29(8), 388-398.

Kolodkin-Gal, I.; Cao, S.; Chai, L.; Bottcher, T.; Kolter, K.; Clardy, J.; Losick, R. (2012). A selfproduced trigger for biofilm disassembly that targets exopolysaccharide. Cell.,149, 684-692. 
Lee, H.Y.; Chai, L.C.; Pui, C.F.; Mustafa, S.; Cheah, Y.K.; Nishibuchi, M.; Radu, S. (2013). Formation of biofilm by Listeria monocytogenes ATCC 19112 at different incubation temperatures and concentrations of sodium chloride. Braz. J. Microbiol., 44, (1), 51-55.

Lowry, O.H.; Rosebrough, N.J.; Farr, A.L.; Randall, R.J. ( 1951). Protein measurement with the FolinPhenol reagents. J. Biol. Chem., 193, 265-275

Marvasi, M.; Visscher, P.T.; Casillas M.L. (2010). Exopolymeric substances (EPS) from Bacillus subtilis : polymers and genes encoding their synthesis. FEMS Microbiol. Lett., 313, 1-9.

Morikawa, M. (2006). Beneficial biofilm formation by industrial bacteria Bacillus subtilis and related species. J. Biosci. Bioeng., 101, $1-8$.

Sauer, K.; Rickard, A.H.; Davies, D.G. (2007). Biofilms and biocomplexicity. Microbes., 2, 347-353.

Savadogo, A.; Savadogo, C.W.; Barro, N.; Ouattara, A.S.; Traore, A.S. (2004). Identification of exopolysaccharides producing lactic acid bacteria from Burkino Faso fermented milk samples, Afr. J . Biotechnol., 3(3), 189-194.

Pagadala, S.; Parveen, S.; Rippen, T.; Luchansky, J.B.; Call, J.E.; Tamplin, M.L.; Porto-Fett, A. C. S. (2012). Prevalence, characterization and sources of Listeria monocytogenes in blue crab (Callinectussapidus) meat and blue crab processing plants. Food Microbiol. , 31(2), 263-270.

Pan, Y.; Breidt, F.; Gorski, L. (2010). Synergistic Effects of Sodium Chloride, Glucose, and Temperatureon Biofilm Formation by Listeria monocytogenes Serotype 1/2a and 4b Strains. Appl. Environ. Microbiol., 76(5), 1433-1441.

Poli, A.; Anzelmo, G.; Nicolaus, B. (2010). Bacterial exopolysaccharides from extreme marine habitats: production, characterization and biological activities. Mar. Drugs., 8, 1779-1802.

Qiang, L.; Yumei, L.; Sheng, H.; Yingzi, L.; Dongxue, S.; Dake, H.; Jiajia, W.; Yanhong, Q. ; Yuxia, Z. (2013). Optimization of fermentation conditions and properties of an exopolysaccharide from Klebsiella sp. H207 and Sapplication in adsorption of hexavalent chromium. PLOS ONE., 8(1), 1-11.

Vidhyalakshmi, R.; Nachiyar, C.V. (2011). Microbial production of exopolysaccharides. J. Pharmacol. Res.,4, 2390-2391.

Vu, B.; Chen, M.; Crawford, R.J.; Ivanova, E.P. (2009). Bacterial extracellular polysaccharides involved in biofilm formation. Mol. Microbiol., 14, 2535-2554.

Wang, Z.; Sheng, J.; Tian, X.; Wu, T.; Liu, W.; Shen, L. (2011). Optimization of the production of exopolysaccharide by Bacillus thuringiensis 27 in sand biological soil crusts and its bioflocculant activity. Afr. J. Microbiol. Rse., 5(16), 2359-2366.

Wong, H.T.L. (2012). An investigation of the regulation and physiological role of Listeria monocytogenes extracellular polymer. PhD Thesis, University of Nottingham.

$\mathrm{Xu}$, C. (2007). Optimized Procedures for Extraction, Purification and Characterization of Exopolymeric Substance (EPS) from Two Bacteria (Sagittula stellata and Pseudomonas fluorescens Biovar II) With Relevance to the Study of Actinide Binding in Aquatic Environment. MSC Thesis, Texas A\&M University. 